\title{
Ringside Seat From a Tractor
}

\section{Hugh McLaughlin, Lewvan}

A tractor seat may not seem the accepted vantage point from which to view nature - but it certainly requires that you put in lots of hours outdoors and in the course of tilling a field, a very thorough coverage is made. There is much to be observed, and in an initmate way. Two birds quite predominate in early field work - the Horned Lark and Killdeer - so will confine remarks to these.

The Horned Lark is a sort of kindred bird who likes, somehow, to stay with us on these plains, as long as food is available in the fall. Then, after a brief abscence in mid-winter, it re-appears in February - a token promise that spring is on the way. We might well wonder why any creature with wings would appear at this stage of the season to brave the last storms of winter. Nevertheless it's cheery voice, as it calls from the vantage point of a little knoll or strawpile, is welcome at this early date.

It generally nests on a site of high ground- the first knolls of summerfallow to become bare of snow - and will usually take advantage of a few sprigs of straw or clump of dirt as protection for its nest from north-west winds. It was quite common this spring to find nests that contain two eggs. Small nests quite often go unnoticed during tillage operations, But the Horned Lark is not hard to find. As the circiut around a field brings you closer and closer every round, the lark will rise from its nest but will not go far away.

Occasionally the implement is almost on top of a nest though, and there is no chance to turn aside. Such was the case thispast April. I quickly carried nest and eggs aside; drove on a few feet and replaced them both. The lark did not move more than ten feet away and was soon back on the nest. The next day, as I went by, I examined her disturbed quarters and was pleased to see two young birds. Later in the week I had to remove a nest with. young in it and then replace it after the discs had passed over the site. Young mouths opened gapingly whenever hands came near. But I did not linger - - whirling discs must continue - there were other mouths to feed

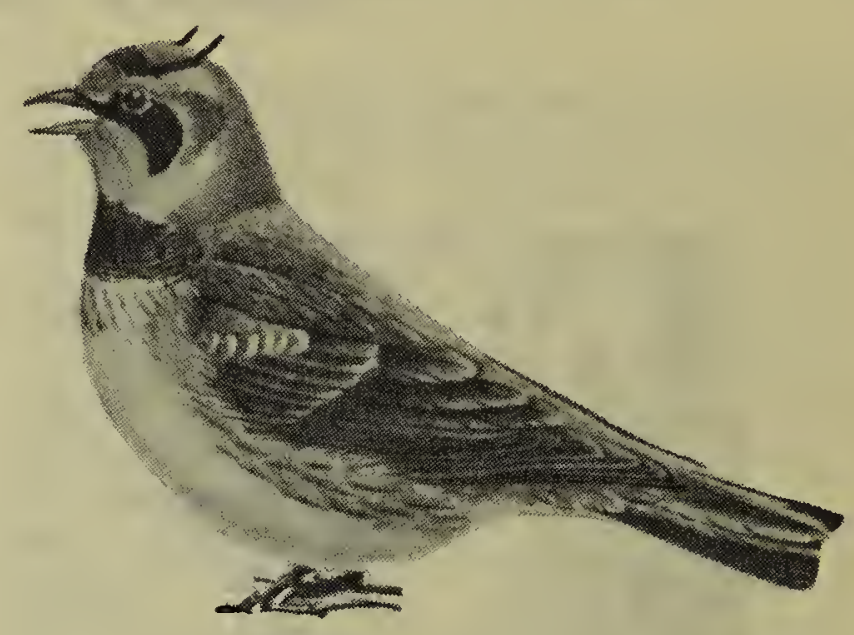

and it was late.

The next morning was cold and frosty and, as was still working close by, I looked to see how the young birds survived in improvised quarters. One had perished, but the other two were alive and Mother Lark was back on the nest as soon as I left. There she stood with outstretched wings covering her two young in the chill morning air. I could see why these early nests contain two or three eggs only. It was hard for such a tiny form to cover growing birds in cold weather - a brave little figure - while the implement passed close by.

A couple of weeks later, a pair of little birds will be trying wings and fluttering out of the way at any approach. They have been well fed on insects gleaned from the field by the lark parents, and in feeding their own children, have helped to feed ours by destroying grain damaging insects - good little partners of the prairie field.

The Killdeers are al so early arrivals. and their noisy approach in spring with chattering "Kildee" is quickly noticed. They also like a bare knoll to nest on - a few pebbles for camouflage and there you are - a home and four eggs that blend remarkably with surroundings. Being a primitive type of bird; the eggs are laid in proportion to the size of the parent. Noisy mother - she squalls at any approach, fan tails her feathers and tries to entise you away with a bright ochre display of color. One, this past spring showed more courage, merely partly rising off the nest and shaking threatening wings. 


\title{
Nipawin Provincial Park
}

\author{
By C. Stuart Francis, Torch River
}

This has been a very ordinary summer as far as ususual happenings are concerned. The weather has been much too wet all through July and early August, but now seems to have improved.

We have made three trips into the Nipawin Provincial Park since July lst. This is a very beautiful region with scores of lakes of various sizes, most of which contain several species of fish. Beautiful rollinghills surround the lakes. In some places the hillsides are so steep that you can throw a. stone into the water below from the top of a 150 or 200 foot hill. The forest is very varied and consists mostly of White and Black Spruce Jack and Banksian Pine, White Birch, Tamarack, Aspen Poplar, Balsam Poplar Balsam Fir, and in some places native Juniper and Box Elder. Pin Cherry, Chokecherry, Hazelnut and Highbush Cranberry are widspread throughout the region.

On August 3rd., while travelling through the Narrow Hills, the native Crocus was observed starting to

\section{Ringside Seat -}

(continued from page 22)

At such a brave dispaly, even a tractor tiller had to turn aside; first to the west side, then to the east. But the nest was never forsaken either time. I believe that when eggs are far on in incubation the birds are inuch more reluctant to fly then when they are still laying eggs.

A couple fo springs ago, while seeding near the buildings and also near Killdeer nest, sudden sleet. storm came blowing in froin the west. Ice pellets that stung the face sent me quickly heading for shelter. Wind that hurled dust and stubble tore in gusts across the field. Horses and cattle raced for the farm. And that night it snowed.

In the warm security of the house, that evening, I wondered if the Kildeer's nest would be thrown away. The answer came a couple of days later one sunny afternoon, when I noticed little fluffy balls on matchstick legs stumbling across the pasture. On rough ground they are easily caught bloom again in more than one spot, on stems two to three inches high, as in early spring. Possibly the very wet weather had something to do with this unusual occurance.

We have recently acquired a lot on which to build a cabin at Fishing Lakes, which is about the centre of the park area. This lake is surrounded with evergreen forests. The lake and the streams near by contain the following species of fish: Northern Pike, Pickeral, Perch, Whitefish, Tulibee and Trout. Out cabin will be situated on a high bank overlooking the lake. It will be about 25 feet above the water on the north-east corner of the lake, in a sheltered location.

In this park are also to be seen many stands of Mistletoe infested Jack Pine. These infested trees are known as "Witches Broom" on account of the odd broom-shaped form of growth of the branches of the entire tree. It reminds one more of a desert or Mexican landscrape, than of Northern Saskatchewan.

and these Kildeer babies were examined and cuddles a bit by the rest of the family and then returned to their anxious parents.

But how any bird could face those stinging pellets - cling to the ground in the wind and keep her eggs warm while an unreasonable snow covered the ground - well that is one of the intriguing things of nauter.

\section{Birding -- (continued from page 9)}

are careless nesters - most of the nests were just hollows in the sand, without lining or cover. Many single eggs lay in the edge of the water, apparently blown from their nests by the wind and waves. Other eggs found back on shore had evidently been eaten by crows. There were between twenty and thirty tern nests in four different locations along half a mile of shoreline. On July 16, some nests still contain eggs, but I banded 24 young which had exchanged their down for feathers and were old enough to swim. 